Pamiętnik Literacki 2013, 4, s. 73-88
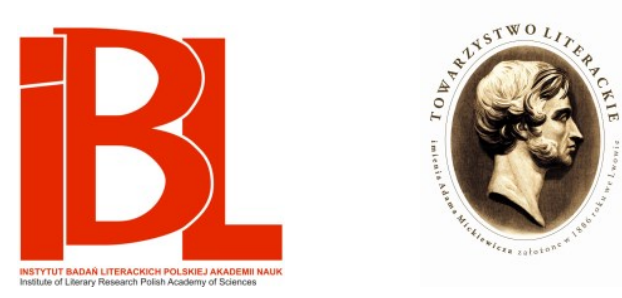

Nosiciel pamięci

O pamiętaniu, kalectwie i pisaniu w twórczości Leo

Lipskiego

Agnieszka Dauksza 


\section{NOSICIEL PAMIĘCI \\ O PAMIĘTANIU, KALECTWIE I PISANIU \\ W TWÓRCZOŚCI LEO LIPSKIEGO}

Rozważając fenomen Leo Lipskiego, oprócz zagładowych wątków jego twórczości oraz powojennych zmagan - rozpatrywanych zarówno w porządku biograficznym, jak i tekstowym - zwykło się uwypuklać skłonności pisarza do epatowania wyuzdaną, niekiedy ocierającą się o pornografię erotyką ${ }^{1}$, portretowanie „obyczajowej graniczności” ${ }^{2}$ oraz upodobanie do przedstawiania obrazów brzydoty, rozpadu, gnicia i ekskrementów, emblematycznie sugerujących kondycję świata po katastrofie ${ }^{3}$. Faktycznie, proza Lipskiego na pierwszy rzut oka jawi się jako świadectwo turpistycznego kultu tego, co trywialne, przyziemne, cherlawe, niekiedy odrażające ${ }^{4}$. Wydaje się jednak, iż w tym przypadku nie chodzi o manierę stylistyczną, o niezdrową fascynację czy o nieuzasadnioną zachciankę pisarza-obsesjonata ${ }^{5}$. Przeciwnie - w niniejszym szkicu chciałabym ukazać, że specyficznie rozumiany antyestetyzm motywowany jest $u$ Lipskiego wielorako. Po pierwsze, nieco nieoczekiwanie, racjami etycznymi. Po wtóre, konwencja przyjęta przez autora Piotrusia stanowi nie tylko świadectwo poszukiwania własnej dykcji, ale także próbę przezwyciężenia powojennego impasu, wykroczenia poza retorykę

1 J. Giedroy c (list do A. B obkows k i e g o, z 16 VII 1960. W: J. Gi edroy c, A. B obk o w s k i, Listy 1946-1961. Wybór, oprac., wstęp J. Z i e l i ń s k i. Warszawa 1997, s. 643) określał powieść Lipskiego jako „obsesyjnie seksualną” i wspominał, że przygotowywany do druku w „Kulturze” Piotruś spotkał się z „oburzeniem” redaktorki, Zofii Hertz, która „odmówiła korekty”.

2 Według określenia S. B e r e s i a (Posłowie. W: L. Li p s k i, Niespokojni. Olsztyn 1998, s. 213)

B. Z $\mathrm{i}$ e lińs ka ( $W$ kloace świata. O „Piotrusiu” Leo Lipskiego. W zb.: Pogranicza wrażliwości w literaturze i kulturze. Red. I. Iwasiów, P. Urbański. Cz. 2: Meandry wrażliwości XX wie$k u$. Szczecin 1999, s. 38, 37) stwierdza: „Symptomy choroby, rozpadu, kruchości porozrzucane są po całym tekście z nadzwyczajną hojnością [...]”; „Swiat ludzki jawi się jako monstrualna kloaka”.

${ }_{4}$ Zob. znamienne w tym kontekście (momentami tendencyjne) opracowanie J. B ł a h e g o Literatura jako lustro. O projekcji i odbiciach fizjologicznych w twórczości Leo Lipskiego (Szczecin 2009).

P. Kr u p iń s k i (Ciało, historia, kultura. Pisarstwo Mariana Pankowskiego i Leo Lipskiego wobec tabu. Szczecin 2011, s. 86) dostrzega wręcz celowość podobnych zabiegów stylistycznych: „Lipski nie szczędzi swoim czytelnikom żadnych szczegółów procesu rozkładu, uchyla zasłonę nawet tam, gdzie jakaś niepisana reguła decorum nakazywałaby pozostawić ją nietkniętą, paradoksalnie jednak czyni to w imię pisarskiej i ludzkiej uczciwości”. 
niewyrażalności, niemocy ekspresji, pustki, wreszcie - staranie mozolnego opowiadania i przedstawiania pomimo zaistniałego kryzysu języka i reprezentacji. Rozpatrywane z tej perspektywy dzieło Lipskiego jest manifestem artystycznym człowieka, który, nie wierząc dłużej w tradycyjną sztukę, paradoksalnie, wyłącznie w niej - lecz koniecznie na nowych zasadach - widzi sens swojej egzystencji. Więcej: w tym, co materialne, perwersyjne, ekskrementowe, cielesne, erotyczne, a często wprost graniczące $\mathrm{z}$ porządkiem śmierci, twórca odnajduje jedyny możliwy budulec sztuki, jedyny akceptowalny bodziec stymulujący dalsze pisanie - ale i trwanie w ogóle. Właśnie rozpoznaniem oraz omówieniem pierwszorzędnych i kluczowych dla Lipskiego elementów, takich jak materia (cielesna i nieożywiona) czy pamięć (ta historyczna i ta ucieleśniona), pragnę zająć się przede wszystkim. Postaram się zatem wykazać zależności między trzema porządkami: fakturami pamięci, materii i tekstu ${ }^{6}$, a co za tym idzie - zastanowić się nad specyfiką pisarstwa Lipskiego, nad fenomenem jego oryginalności (również na tle dzieł tematyzujących traumę wojny, zwłaszcza kanonu literatury łagrowej) i wreszcie - nad przyczynami niepoczytności prac tego autora. Spowinowacenie porządków pozornie nieprzystających lub - przynajmniej zwykle - rażących w dyskursie zagładowym wydaje się bowiem istotnym wyróżnikiem omawianej twórczości, funkcjonującym na wielu poziomach wypowiedzi, ale i decydującym o spoistości, a zarazem o wyjątkowości artystycznego projektu Lipskiego.

\section{Faktury pamięci}

Proza tego autora obfituje w rozproszone, acz wyraziste, wzmianki dotyczące procesów pamięciowych. Często ponawiane są próby okiełznania niepokornej pamięci, przedarcia się przez warstwy nie-pamięci, wysiłki selekcjonowania i „konserwowania” wspomnień, które u Lipskiego opisywane bywają zwykle jako amalgamaty przeżyciowo-zmysłowo-afektywne. Dzieje się tak m.in. w Paryżu ze złota, czyli w osobliwej relacji z odbytej w połowie lat siedemdziesiątych XX wieku podróży Lipskiego do stolicy Francji. Wówczas to Lipski ubolewa z powodu zawodności swej pamięci („Moja chłonność ani pamięć nie jest dużą” $\langle\mathrm{P} 33\rangle^{7}$ ) oraz - w nieco żartobliwym tonie - niemożności pochwycenia ulotnych wrażeń zmysłowych: „Chciałbym, by istniało, na równi z Towarzystwem Ochrony Przyrody, Towarzystwo Ochrony Pamięci. To, co przeżyłem w Paryżu, jest tak dla mnie wyjątkowe [...]" (P 10). Przez emocjonalne wzmianki o kolejnych spotkaniach z przyjaciółmi (np. „Żegnamy się z Andrzejem nieśmiało. I to pożegnanie jest może najboleśniejsze, gorzkie, wyjątkowo przytomne" $\langle$ P 29〉) oraz impresje z paryskiego życia (np. „Wracamy paryskimi ulicami. [...] [są one] zależnie od nastroju uroczo-smutne, uroczo-wesołe, gorzkie - nigdy bezbarwne" $\langle$ P 34〉) palimpsestowo przezierają jednak reminiscencje jeszcze innego typu:

6 Nawiązuję tu do koncepcji E. D o m a ń s k i e j (Historia egzystencjalna. Krytyczne studium narratywizmu i humanistyki zaangażowanej. Warszawa 2012), stwierdzającej celowość badania „fakturowości” historii (zwłaszcza w jej wymiarze materialnym).

Skrótem tym odsyłam do zbioru L. L i p s k i e g o Paryż ze złota. Teksty rozproszone (Wybór, oprac., posł. H. G o s k. Izabelin 2002). Ponadto stosuję skrót Ś = L. L i p s k i, Smierć i dziewczyna. Opowiadania. Lublin 1991. Liczby po skrótach wskazują stronice. 
Wracamy do hotelu. Przychodzi Kosko. Staszek kupuje flaszkę whisky [...]. [...]

[...] Opowiada o swoich teoriach sztuki, opowiada świetnie, przykuwająco, przynajmniej dla mnie, którym go takim nie słyszałem od 1940 roku. Słuchałem tego, co mówił, tak jakby między Krakowem a Paryżem nie było żadnej luki, szukałem oczyma Kubka i Julka, dziwiłem się trochę, że nie ma w pokoju fortepianu, że nie ma Ali Orkan. [P 23]

W narracji o paryskich wypadkach co rusz pojawiają się nostalgiczne przebłyski wspomnień o przedwojennej rzeczywistości, nieodmiennie postrzeganej przez pryzmat późniejszej katastrofy. Paryż traktowany jest wówczas jako „nieistniejący Kraków-Paryż”, możliwe miasto powrotu. Chwilowe ułudy każe jednak racjonalizować i kwestionować konsekwentna nieobecność dawnych znajomych, a także świadomość własnego położenia, kalectwa, emigracji, osamotnienia itd. Bolesne konstatacje niechybnie prowadzą z kolei do refleksji na temat wydarzeń wojennych, neurotycznie przywoływanych w kolejnych ujęciach i odsłonach.

W rezultacie - biorąc pod uwagę tematyczną dominantę analizowanego dorobku - blisko dziełu Lipskiego do osobliwego, tworzonego niekonwencjonalnymi środkami wyrazu, traktatu o procesach pamięciowych. Wykorzystując trafne określenie Hanny Gosk, piszącej (w odniesieniu do sposobu kształtowania reminiscencyjnych konstrukcji myślowych w Paryżu ze złota) o ,„przełącznikach « narracji wspomnieniowej" 8 , można zaryzykować stwierdzenie, iż wiele (z tej perspektywy) „pobocznych”, tzn. „niepamięciowych”, wątków omawianej prozy stanowi właśnie takie ,przełączniki”, które ewokują ciągi reminiscencji w złożonej, wielowątkowej i konsekwentnie prowadzonej opowieści Lipskiego o meandrach pamięci i zapominania właśnie.

\section{Pamięć jako pożywka}

Powojenne losy pisarza $\mathrm{w}$ istocie zdominowane zostały nie tylko przez zmaganie ze wzrastającym poczuciem wyobcowania - społecznego, psychicznego, cielesnego - oraz przez trwanie pomimo cierpienia, powodowanego postępującą chorobą. Decydujące było wrażenie uwewnętrznienia wojennych obrazów, stanowiących odtąd niezbywalny inkluz, zarazem krępujący kolejne wybory i - siłą rzeczy - wyznaczający ramy dalszej egzystencji:

Łóżka były dla nas (często) jedyną ucieczką i chowaliśmy się do nich pod lada pretekstem... byliśmy biedni i głodni [...]. [...] O roku ów... przypominający naszą dzisiejszą rzeczywistość... może dlatego, że wojna, tak czy inaczej, dla nas ciągle trwa... Teraz czujemy się więźniami czasu... podczas gdy wtedy czas wydawał się nam nieograniczony. [P 21]

Nieustanne powracanie do owego roku lokuje się w rozpoznanym przez Michaela Rothberga wymiarze pamięci wielokierunkowej ${ }^{9}$; innymi słowy: pozostawanie we władzy minionego wymusza ustawiczne konfrontowanie porządków przeszłości i teraźniejszości, kompulsywne cofanie się do punktu granicznego, którym okazał się początek wojennego koszmaru. Bohaterowie Lipskiego zmagają się z niemożnością przystosowania się do realiów i odnalezienia swego miejsca we wspólnocie (,Szedłem wśród ludzi, ale zawsze wyskakiwałem niby korek, nie

8 H. G o s k, Jesteś sam w swojej drodze. O twórczości Leo Lipskiego. Izabelin 1998, s. 148.

9 M. R o th b e rg, Między Auschwitz a Algierią. Pamięć wielokierunkowa i świadek przeciw-publiczny. Przeł. K. B oj a r s k a. „Teksty Drugie” 2012, nr 4. 
mogłem w nich wejść" 〈Ś 87〉), co zresztą bezpośrednio zbiega się z poczuciem nieokreślonego wstydu, zwątpienia, winy. Przeszłość rzutuje na aktualne wybory, obecna perspektywa z kolei zmusza do retroaktywnego odczytywania minionych zdarzeń. Co ciekawe, pamięciowa neurastenia okazuje się przypadłością tyleż psychiczną, ile głęboko ucieleśnioną. Zasada ta jest widoczna na poziomie literackiego obrazowania, np. gdy autor porównuje swoje zmagania do rozpaczliwej walki ranionego zwierzęcia:

A ono siedzi we mnie. Nie można tego wypluć. Łażę wzdłuż bulwarów, ale to nie pomaga. Zwierzę, któremu utkwiła strzała w grzbiecie, tarza się, biega, ryczy, krew zalewa mu oczy; strzała tkwi. Nie ma ludzi i nikt nie wyciągnie strzały. Każdy z nas jest zamknięty we własnej nocy, sam. [Ś 17]

Widać wyraźnie, że te karkołomne samotne starania są walką z czymś jeszcze - nieokreślonym, niesprecyzowanym, ewokowanym szeregiem ogólnikowych zaimków („ono”, „to”), co prawda, doskonale wyczuwalnym, wciąż doskwierającym, lecz z jakichś względów opierającym się intelektualnemu i językowemu skategoryzowaniu. Próby pozbycia się, zgubienia, „wyplucia” owego „czegoś” kończą się jednak fiaskiem. W konsekwencji „działania obronne” przybierają postać dążności do zwerbalizowania i pisarskiego sproblematyzowania nękających kwestii. W kolejnych odsłonach literackich Lipski eksplikuje potrzebę zdiagnozowania własnego stanu. Ostatecznie - wskutek podjęcia afektywno-racjonalizującej próby przepracowania problemu (dostrzegalnej $n b$. w rozważaniach powieściowego alter ego autora, Piotrusia) - dochodzi do rozpoznania przyczyn udręki. Lipski określa ten mechanizm jako swoisty ,powrót realnego”:

Czułem, że czegoś nie rozumiem. Jakbym był oślepiony w pewnym punkcie. Usiłowałem nadaremnie przypomnieć sobie to, co zapomniałem. Ale byłem pewien, że coś tam było jeszcze. I nagle zrozumiałem, że tego nigdy nie zobaczę. To nie było do patrzenia ani do rozumienia. To była część śmierci. [P 128]

Niedawne przeżycia wojenne okazują się niezbywalnym inkluzem, nieusuwalną, stale tkwiącą w grzbiecie strzałą. I właśnie w tym punkcie znajduje się miejsce bolesne (o którym pisze Ernst van Alphen ${ }^{10}$ ), wciąż niezabliźnione i nieprzepracowane, w jakiś sposób zatruwające cały układ psychosomatyczny. Chwilowo wyparte, ,gnijące” na dnie świadomości obrazy i wrażenia jednoznacznie lokujące się po stronie śmierci, więcej: będące „częścią śmierci”, powracają teraz ze zdwojoną mocą, oślepiają, infekują, domagają się wypowiedzenia. „Zrozumienie” czy raczej przeczucie istoty tego, co nie może podlegać racjonalizacji, paradoksalnie, przynosi pewną ulgę. Odtąd Lipski - choć skazany na życie z trudną pamięcią - świadom jest położenia nieokreślonego wcześniej ,ślepego punktu”, miejsca bolesnego. Podejmuje się roli fizjologa pamięci, która w jego opisie funkcjonuje jako nadaktywny, materialny twór, żywy organ, wpływający na kondycję całego układu psychocielesnego:

gniję pomału. Wyciekam z siebie powoli, zostaje miękka skorupa, zdeformowany kształt. Jem przeszłość, jak gdybym jadł własny kał, przeżuwam ją ciągle na nowo i znów od początku. To jak łykanie śliny, gdy się chce pić. [Ś 17]

${ }^{10}$ E. v a n A $1 \mathrm{p}$ h e n, Art in Mind: How Contemporary Images Shape Thought. Chicago 2005. 
Przytoczony passus jest - w moim przekonaniu - kluczowy dla rozumienia koncepcji Lipskiego. Jeśli pokusić się o dokonanie segmentacji tego krótkiego, acz bogatego w znaczenia, fragmentu, okaże się, że dochodzi w nim do spowinowacenia najistotniejszych dla omawianej twórczości wątków, problemów i obrazów. Analizując kolejno każde z wyrażeń, wyróżnić można następujące całości:

1. „gniję" - odsyłające do stale rozważanego „fenomenu gnicia” "11, przedstawianego m.in. jako wszechobecnie gnijąca materia w opowiadaniach łagrowych, zgnilizna śmierci, fekalia, pejzaż zainfekowany resztkami i odchodami, skażona woda (śmiercionośna „waadi”), gnijące zwłoki, podgniwające za życia, brudne ciało pani Cin, wreszcie - metaforyczne ,gnicie”, zapadanie się, rozpadanie chorego, kalekiego ciała tytułowego Piotrusia. Co interesujące, owo gnicie nie jest u Lipskiego nacechowane pejoratywnie, przeciwnie - ukazuje się je jako zjawisko najbardziej elementarne, najbliższe człowiekowi, stanowiące istotę (kres, ale i początek) biologicznego życia, podstawowe także dla procesu twórczego - wszak kolokwialna retoryka „skatologiczna” stanowi stały budulec tej prozy. Więcej: właśnie poprzez eksponowanie fenomenu gnicia Lipski realizuje co najmniej kilka pisarskich zamiarów: po pierwsze, w relacji z doświadczeń łagrowych przedstawia wydelikacenie europejskich ciał $\mathrm{i}$ umysłów porażanych intensywnością azjatyckich realiów; po drugie - co szczególnie godne uwagi - konstatuje fasadowość i faktyczną kruchość zachodnioeuropejskiej kultury, której wyczerpanie obnaża kilkunastoma zaledwie słowami: „Wszyscy mieli biegunkę. Nawet najpiękniejsze dziewczęta. [...] Zależnie od talentu erotycznego podcierały się kartkami z Lenina, kamieniami, albo w ogóle nie" (Ś 62). Po trzecie wreszcie, konsekwentną metaforyką gnilno-fekalną a) wskazuje na kryzys tradycyjnego modelu reprezentacji (zawodnego w przypadku prób przedstawiania przeżyć wojennych), b) bada „pojemność” literackiego języka jako nośnika ludzkiego doświadczenia, c) godzi w dotąd wypracowane konwencje pisania o przeżyciach czasu Zagłady, d) testuje granice czytelniczej wrażliwości etycznej i wytrzymałości estetycznej (o czym szerzej dalej).

2. „pomału” (następnie także ,powoli”) - rozpatrywane z perspektywy biografii pisarza, nie tającego chorobowego piętna odciskającego się na kształcie jego prac, okazuje się wymownym znakiem powolności i - co gorsza - nieuchronności postępującego kalectwa. Podporządkowany dolegliwościom styl życia oraz mozolny sposób tworzenia zbiegają się z umieraniem ,pomału”, z umieraniem za życia, z pełną świadomością i koniecznością rejestrowania kolejnych faz rozpadu ,gnijącego" ciała.

3. „Wyciekam z siebie” - zwrot ten sugeruje binarne postrzeganie własnego systemu psychosomatycznego, zakłada bowiem istnienie jakiegoś ,ja”, jaźni czy umysłu nietożsamego z cielesnością. Co jednak ciekawe, perspektywa binarna, dosyć nietypowo, złagodzona zostaje przez dowartościowanie obu „poziomów” jednostki - nadrzędna część, ludzkie ,ja”, zawiera się, co prawda, w formie gramatycznej czasownika (,ja” wyciekam), jednakże owo „z siebie”, oznaczające nie pierwiastek duchowy, lecz właśnie powłokę cielesną - najczęściej deprecjonowaną w tradycji modernistycznej - świadczy o tym, że podmiot traktuje ciało jako

${ }^{11}$ Zob. interesujące studia M. C u b e r (w tym kontekście szczególnie szkice: Muchy. O „,Waadi ” i ,C Coś” marzenia. ,, Niespokojni” jako przypadek literackiej koprofagii) zgromadzone w książce Trofea wyobraźni. O prozie Leo Lipskiego (Katowice 2011). 
pełnoprawną, integralną część układu. Ponadto „wyciekanie” odwołuje się także do istotnej w systemie Lipskiego symboliki cieczy/płynu, wykraczającej poza typowe zachodnie wyobrażenie cieczy, szczególnie wody, jako znaku czystości, odnowy ${ }^{12}$. U autora Piotrusia przeciwnie - woda kojarzona jest na ogół z niebezpieczeństwem, brudem, skażeniem. I więcej: ludzkie wydzieliny, zwyczajowo wzbudzające wstręt w kulturze europejskiej, są w omawianej twórczości tożsame $\mathrm{z}$ witalnością, ciągłością, obiegiem, cyklem przyrody itd.

4. „zostaje miękka skorupa” - to zapewne figuracja niedoskonałej, kalekiej cielesności, która ukazywana bywa u Lipskiego także jako swoiste więzienie, cela. W tym jednak przypadku oksymoroniczna „miękkość” owej „skorupy” sugeruje utratę sił fizycznych, impotencję życiową, pasywność, słabnięcie, bezwład. Znamienna w przywoływanym kontekście jest inna wypowiedź Lipskiego:

Gwałtowna atrofia: kurczę się, zostaje ze mnie tylko fasada, która mówi, śmieje się. [...] $[\ldots]$

[...] ulgę sprawia słuchanie tykania zegarka, wąchanie wody kolońskiej, lizanie i całowanie poręczy krzeseł [...]. [S 88]

5. „Zdeformowany kształt” - kaleka cielesność okazuje się dla Lipskiego w jakiś sposób niepokojąca, obca, nie-ludzka. Z drugiej strony, w prozie tego autora widać wyraźną fascynację tym, co abiektualne, niejednoznaczne, niepochwytne $\mathrm{w}$ formę, zdeformowane czy wprost bezkształtne. Podobne zainteresowania pozwalają lokować inspiracje literackie omawianego pisarza w kręgu francuskiej awangardy, zwłaszcza Georges’a Bataille’a i Michela Leirisa ( $n b$. kwestia ta domaga się osobnego opracowania).

6. ,jak gdybym” - odsyła do stale eksponowanego w twórczości Lipskiego poczucia pozorności, nietrwałości, sztuczności, konieczności wcielania się w role i przyjmowania masek, znamiennych - jak zdaje się sugerować autor - dla okresu powojennego:

Wszystko jest prowizoryczne. Szyld czasu TYMCZASEM. Jestem nieobecny tam, gdzie chciałbym być najbardziej. Epoka wiruje jak bąk, w jakimś dziwnym nie na-serio. Jakaś niepewność, czy się jest. Stale. Naprawdę. [Ś 87]

7. ,jadł własny kał” - typowe dla Lipskiego skatologiczne obrazowanie wiąże się z fascynacją biologizmem i przyrodniczym cyklem obiegu materii, z uwznioślaniem rangi resztki i odpadu, wreszcie - z przekonaniem o recyklingowym potencjale kultury i tradycji („Kał nie jest martwy. On jest początkiem wszystkiego. [...] Z niego można jeszcze, jeszcze wszystko zrobić" $\langle$ S 88$\rangle)$.

8. „Jem/przeżuwam przeszłość” - wspomnienia figurowane są w tym przypadku jako materialne twory, wyłączna pożywka dla straumatyzowanej jednostki. Z kolei pamiętanie i przypominanie - o które głównie toczy się gra w egzystencjalno-artystycznym projekcie Lipskiego ${ }^{13}$ - jawią się w owym układzie jako czynność fizjologiczna organizmu.

12 Więcej o „metaforyce płynów” i odwróceniu tradycyjnych porządków sacrum i profanum zob. ibidem, s. $148-150$.

${ }_{13}$ Trafna wydaje się konstatacja C u be r (ibidem, s. 62) na temat ,zmysłowej, czuciowo-węchowej, nekrofilskiej” specyfiki pamięci Lipskiego, trudno jednakże zgodzić się, że ta sama pamięć jest „posłuszna zaklęciu, poddająca się magii opowiadacza, ekstatyczna i w końcu zwycięska” 
9. ,ciągle na nowo i znów od początku” - nawiązuje do nieuchronności i powtarzalności rzeczonych procesów i wskazuje na ich kompulsywny charakter, na swoiste ,zapętlenie” czy „zafiksowanie” w konkretnym schemacie działań i myślenia. Uwewnętrznienie zdarzeń z przeszłości, analizowanie, przetwarzanie, próby werbalizacji i podejmowane czynności pisarskie wyznaczają bowiem pewien cykl, który można określić mianem recyklingowej obróbki faktur materii i tekstu (o czym szerzej w dalszych częściach artykułu).

10. „łykanie śliny, gdy się chce pić” - oddaje niewystarczalność, jałowość, czczość dokonywanych przez Lipskiego aktów.

Zatem metafora żywienia się wspomnieniami - tyleż wyjaławiającego i niesycącego, ile nieodzownego - wskazuje na opresyjność czy destruktywność minionych doświadczeń oraz na ich fundacyjny charakter, zarówno w wymiarze egzystencjalnym, jak i artystycznym. Bolesna pamięć stanowi bowiem pożywkę dla procesu twórczego, w którym Lipski wciąż na nowo układa się z ,uczuciami sterczącymi z mroku przeszłości” (P 117).

Przywołane metafory uświadamiają także prawidłowość ekonomii pamiętania, charakterystyczną dla autora omawianej prozy. Postaci z jego tekstowych światów nie bez kozery bowiem tak często odczuwają niestosowność pamięciowego zafiksowania. Tytułowy Piotruś już w pierwszej powieściowej scenie - wykupienia z telawiwskiego szuku - w konfrontacji z panią Cin spostrzega wyobcowującą niewygodę pamiętania. Stwierdza: „Wtem zrozumiałem, że za dużo pamiętam. Że popełniłem fatalny błąd" (Ś 77). Owym błędem nazywa bohater publiczne przyznawanie się do doświadczeń okresu wojennego - jak zresztą wiadomo, początkowo często deprecjonowanych w późniejszym europejskim, ale także izraelskim, dyskursie polityki pamięci. Konsekwencją jest poczucie wyobcowania. Okaleczona psychika i dyktat wzmożonej pracy pamięci skazują na permanentną niemal samotność ${ }^{14}$ : „Ludzie odpadają ode mnie, jak liście z więdnącego drzewa. Samotność krąży nade mną jak ptak, jak wiatr, jak burza [...]" - pisze Lipski w jednym z wariantów prozatorskich (P 97). Ów „Żywioł” samotności, z którym konfrontują się bohaterowie, stanowi zresztą częsty temat jego utworów. Wystarczy przywołać sytuacje egzystencjalne głównych postaci literackich: począwszy od mogącego liczyć wyłącznie na siebie, walczącego o przetrwanie więźnia obozowego, przez chorego odizolowanego od aktywnego nurtu życia, po osobę napiętnowaną wielowymiarową, „Zwielokrotnioną" i radykalną odmiennością - Żyda, kalekę, emigranta i - co stale podkreśla Lipski - nosiciela wspomnień, z jakimi nie sposób się pogodzić.

\section{Faktury materii}

O tym, że owo „noszenie” pamięci nie jest wyłącznie metaforą, lecz faktycznym piętnem, znajdującym analogię także w wymiarze materialnym, przekonuje choćby

\footnotetext{
- wystarczy wszak skonfrontować te diagnozy ze statusem pamięci w Świętym Pawle czy w Sarnim braciszku.

${ }_{14}$ Zob. D. K r a w c z y ń s k a, Nagie życie Leo Lipskiego. (Wstęp). „Teksty Drugie” 2010, nr 6. Podobne wątki poruszała badaczka w referacie „Mówię - nie rozumieja mnie..." Leo Lipski $i$ doświadczenie samotności, wygłoszonym podczas XXXIV Konferencji Teoretycznoliterackiej Literackie reprezentacje doświadczenia (Gdańsk, 19-22 IX 2006).
} 
sposób, w jaki ocenia się powieściowego Piotrusia. Przykładowo, w przywoływanej już scenie wykupienia przez panią Cin pojawia się fragment następujący:

Podeszła do mnie starsza pani, czarno ubrana. Zbliżyła twarz do mojej, mokrej z potu. Poczułem smród jej ust, fetor nieznośny. [...] Kucnęła. Zaczęła mnie gruntownie macać. Nie pominęła żadnej części ciała. Kazała wstać. Uczyniłem to niezgrabnie. „Aha” - mruknęła. Macała mnie dokładnie, niby kurę, czy ma jajka, czy jest tłusta. Bała się, widać, bym nie był dostatecznie zdrów ani też zbyt chory [...]. [Ś 76-77]

Nabywczyni Piotrusia w mig dostrzega ,warstwowość” jego dolegliwości-nie tylko pamięciowe zafiksowanie, ale także fizyczne niedołęstwo. Kolejni bohaterowie dokonują analogicznych odkryć i - co istotne - każdorazowo spowinowacają oba typy przypadłości, traktując najwidoczniej (podobnie jak starożytni) piętno cielesne jako odzwierciedlenie stanu ducha. Doktor Siegbert błyskawicznie identyfikuje pacjenta „skomplikowanego”, który „,nie jest przypadkiem o określonej diagnozie" i który „urządził sobie prywatną Golgotę" (Ś 120). Batia natomiast na samym wstępie ucina wzmianki Piotrusia o chorobie lakonicznym: „Już znam tę piosenkę" (S 91):

Więc ona naga, ciało dziewczynkowate [...]. [...] Stojąc, gdy ja leżę, mówi:

- Może się odzwyczaisz od swojej choroby?

- Jak to, odzwyczaisz?

- No, po prostu... nie będziesz chory.

- Ale ja...

- To jest brzydkie przyzwyczajenie i kto wie, czy ty tego nie symulujesz.

$[\ldots]$

Po dłuższej chwili spytała:

- Jak to się stało? [S 100]

Doktor Siegbert i Batia nie wytykają bynajmniej powieściowemu Piotrusiowi hipochondrii czy pozorowania kalectwa - widocznego przecież na pierwszy rzut oka - lecz raczej skłonność do kontemplowania choroby nie tyle fizycznej, ile jakiejś innej, głęboko uwewnętrznionej, mentalnej, jednakże doskonale wyczuwalnej przez otoczenie, być może stanowiącej „rewers” cielesnej ułomności. Ciekawe $\mathrm{z}$ tej perspektywy jest rozważanie zasadności Cioranowskiej formuły emigracji jako choroby ${ }^{15}$ ( $n b$. sama emigracja stanowiła dla Lipskiego jedną z głównych bolączek). Piotr Krupiński, analizując owo zagadnienie, odwraca porządki, by mówić o chorobie jako o emigracji i dalej - o chorobie jako o przysłudze, ,nieoczekiwanym i niezasłużonym proficie" ${ }^{16}$. Jeśli pokusić się o wykorzystanie tych metafor, okaże się, że w symptomach bohaterów Lipskiego można dostrzec swoistą satysfakcję z własnego cierpienia fizycznego i z kalectwa, będących - paradoksalnie - zarazem „odskocznią” od udręki pamiętania i specyficzną maską, fasadą ukrywającą okaleczoną pamięć.

\section{Ciało jako nośnik pamięci}

W dorobku Lipskiego napotyka się wiele rozproszonych wzmianek, gdzie dochodzi do sugestywnego przeplatania się literackich faktur pamięci i faktur s. 53.

${ }^{15}$ É. M. C i o r a n, Zalety emigracji. W: Pokusa istnienia. Przeł. K. J a r o s z. Warszawa 2003,

${ }^{16}$ Krupińs ki, op. cit., s. 70. 
materii, mającego zresztą źródło w zależności między okaleczoną pamięcią a kalectwem ciała. W jednym z fragmentów prozy autor zauważa: „Przeżycia osiadają na naszej twarzy jak pył” (P 80), następnie w Piotrusiu: „Życie osiada na twarzy jak pył" (S 86). Pozornie niewinne stwierdzenia znajdują analogię na kolejnych poziomach tekstu. Dotknięty nieuleczalną, od 1944 roku nieodmiennie postępującą chorobą, prawostronnie sparaliżowany pisarz wielokrotnie określa swój stan jako „kamienienie”, ,zamurowywanie”, przeistaczanie się za życia w martwą strukturę, fasadę, pomnik. Podobna metaforyka ma, oczywiście, referencje w porządku biograficznym i w pogarszającej się kondycji fizycznej autora, który samemu sobie wieszczy stopniową przemianę w rzecz martwą:

Los rzecze:

$[\ldots]$

W końcu cofniesz się w głąb samego siebie, zostawiając fasadę mówiącą, śmiejącą się.

Wtedy wejdą zwierzęta do twego pokoju i siądą na tobie spokojnie, jak na kamieniu i ziemi. [P 48]

„Rzeczowienie” nie tyle nawet samego ciała, ile fizycznej osoby jako takiej potwierdzają także konfrontacje z innymi powieściowymi postaciami. Batia początkowo odnosi się do Piotrusia z niejakim wstrętem, odczuwanym wobec tworów nie-ludzkich:

Przede mną jest dziewczynka piętnastoletnia. Może ma szesnaście. Mówi, spoglądając na mnie z obrzydzeniem:

- Ciocia prosiła, aby pana dziś wypuścić.

Patrzy na mnie jak na glistę, karakona. [...]

$[\ldots]$

[...] Patrzy na mnie jak na tarantulę. Ale bez strachu, z ciekawością. [Ś 90-91]

Z upływem czasu jednak Batia zmienia sposób oglądu - teraz traktuje głównego bohatera jak rzecz: „Patrzyła na mnie jak na przedmiot martwy” (S 95), później „zarzuca go na ramię”, „chowa do bagażnika” (Ś 103) itd. Te symboliczne akty reifikacji zbiegają się z intensyfikacją metaforyki wskazującej na proces „kamienienia” ciała, ,zamurowywania się" w przeszłościowym porządku myślenia, wreszcie - „sedymentacji” wspomnień i materializowania czy wręcz „,ieleśnienia” pamięci. Odtąd bowiem człowiek zamienia się w żywy pomnik, rzecz do pamiętania, mającą przypominać, świadczyć, ale także napominać.

$\mathrm{W}$ rezultacie chorobowy syndrom zamknięcia we własnym ciele - zmuszający do radykalnego dualizowania sfery materii i świadomości - wymaga postrzegania somatycznej powłoki jako tkanki obcej, nie-ludzkiej, zarazem stygmatyzującej (jako reprezentacji jednostki wobec innych) i opresyjnej (wobec bezbronnego, świadomościowego ,ja”). Kalectwo cielesne ogranicza i upośledza funkcjonowanie nadaktywnej psychiki, zdanej odtąd na udrękę rejestrowania rozpadu somy. Choroba powoduje afazję, faktycznie utrudnia procesy twórcze, uniemożliwia mobilność, odbiera samodzielność i poczucie godności, wreszcie - prowadzi do fiaska wszelkich relacji interpersonalnych. Można by się zatem spodziewać, że kaleka cielesność okaże się dla Lipskiego największym życiowym dramatem, praprzyczyną wszystkich kolejnych cierpień i upokorzeń. Wydaje się jednak, iż z pewnych względów tak się nie dzieje.

Trzeba zaryzykować może kontrowersyjne na pierwszy rzut oka, lecz - jak 
mniemam - uzasadnialne stwierdzenie: chore ciało jest dla Lipskiego głównym nośnikiem pamięci, epatowanie kalectwem - metodą tworzenia i formą autoprezentacji; choroba w ogóle - usprawiedliwieniem trwania oraz stymulatorem pisania; pisanie zaś - najistotniejszym momentem etycznym i zarazem jedynym sensem egzystencji.

Pewną przesłankę do tej konstatacji stanowi sposób, w jaki autor Piotrusia postrzega cielesne defekty, widoczny np. wtedy, gdy przywołuje postać anonimowego generała:

żądał absolutnie, aby mu sparaliżowaną rękę umieszczono „w nogach”, aby mu nie przeszkadzała; twierdził, że to jest nie jego ręka. I ordynans powtarzał w kółko: „Melduję, panie generale, że już kładę". [P 68]

Okaleczony podczas wojny wojskowy odrzuca zdefektowaną część ciała, uznając ją za nieintegralną, obcą, zagrażającą spoistości systemu psychosomatycznego. Kontekst anegdoty sugeruje, iż w tym przypadku Lipski utożsamia brak akceptacji chorej części ciała z niemożnością pogodzenia się ze wspomnieniami. Gest odsunięcia sparaliżowanej ręki ma być równoznaczny z wypieraniem traumatycznego doświadczenia. O podobną ekonomię pamiętania i zapominania posądza Lipski społeczeństwo izraelskie, pisząc w Piotrusiu o osobliwych zachowaniach mieszkańców Tel Awiwu:

Myślałem o dziwnym wrażeniu, które towarzyszyło mi przez cały czas [...]. [...]

Chodzi mianowicie o dłubanie w nosie. Każdy wszędzie dłubał w nosie, widocznie czy też psychicznie. I każdy wyciągał smarki na wierzch, szukał w nich czegoś długo, szukał, szukał [...]. I każdy też ruszał najbardziej intymne miejsca ręką czy też nogą. Naturalnie, nieczęsto fizycznie, ale jakąśs trzecią nogą, której zarysy wyraźnie widziałem. [...]

- Taki już naród - myślałem - wybrany przez Boga też tym. Wielka neuroza, jedno wielkie skomplikowanie, które rozgałęzia się jak arteria i kończy się dłubaniem, oglądaniem. [Ś 78-79]

W tym przypadku symptomem jest kompulsywne, zapewne mimowolne i zapewniające poczucie bezpieczeństwa, dotykanie, wyciąganie, przeszukiwanie, penetrowanie. Można sądzić, że Lipski w tej ironicznej krytyce żydowskiego społeczeństwa wskazuje na grzechy poniechania. Opisywane gesty rozumiane są bowiem jako czynności zastępcze, odsuwające gnębiące przekonanie o konieczności przeanalizowania, przemyślenia czy przepracowania wydarzeń Zagłady.

Strategia samego Lipskiego jest nieco odmienna. Jego tekstowe alter ego zdają się dopatrywać we własnym kalectwie wojennego piętna, które zarazem dosłownie świadczy o skali ówczesnego wyczerpania fizycznego i wymownie prezentuje stan psychiki. „Zamurowanie” w ciele oznaczałoby w owym przypadku także „zamurowanie” w przeszłościowym porządku. Dochodziłoby tym sposobem do paradoksalnego wykroczenia poza dualistyczną opozycję cielesnego i duchowego. Pamięć i soma koegzystowałyby odtąd w nierozerwalnym układzie, oddziałując na siebie i zarazem niejako infekując się wzajemnie. Stopniowe „kamienienie" czy urzeczowianie ciała następowałoby równocześnie z tężeniem tkanki wspomnieniowej. Zatem podwójny (mentalny i fizyczny) stygmat określa jednostkę w dwójnasób, ponieważ świadcząc - nie pozwala zapomnieć; przypominając - karze ,pokutą” pamiętania.

I nie chodzi tu wyłącznie o wizje łagrowego koszmaru: przebytego w niewoli 
tyfusu, skrajnego wyniszczenia i wreszcie paraliżu. Wydaje się bowiem, iż - nieco nieoczekiwanie - traumę pisarza stanowią nie tylko własne przeżycia z łagru, lecz przede wszystkim cudze cierpienia obozowe. Innymi słowy, bolesnym punktem okazuje się niemożność bezpośredniego uczestnictwa w tragicznych wydarzeniach Zagłady. Żal ów Lipski wyraża wprost w passusie poprzedzającym fragment prozy o „,sarnim braciszku”. Wyjaśnia: „Dzień i noc nazywa się tom moich szkiców sowieckich; tym tekstem [tj. Sarnim braciszkiem] pragnę zmniejszyć poczucie winy, że nie byłem także z drugiej strony" (Ś 149). Również w samej narracji autor przyznaje się do poczucia odpowiedzialności za bezmiar wyrządzonych krzywd oraz do bezgranicznego wstydu z powodu własnego ocalenia ${ }^{17}$ :

On [tj. „sarni braciszek”] już odchodzi ode mnie, zasnuwa się mgłą. Gdy jemu się coś stało, to nie mamy prawa istnieć, ani ja, ani Ty. [ŚS 150]

I działo się to na rogu ulicy Bożego Ciała, koło kościoła Bożego Ciała, niedaleko Skałki.

W trakcie próby „odpominania” mar przeszłości raz jeszcze ukazywany jest - wysoce wadliwy, jak sugeruje Lipski - mechanizm wnikliwego studiowania delikatnej tkanki wspomnień. Postać żydowskiego chłopca poznanego w przedwojennym Krakowie z perspektywy czasu wydaje się bytem idealnym, nie tyle nawet nie zasługującym na przeminięcie, ile wprost nieodzownym dla spoistości otaczającego świata. Jednak ,schizofreniczna epoka”, eliminując najdoskonalsze wytwory, wydała wyrok tak samo niesprawiedliwy jak kuriozalny. Odtąd bowiem zjawiska opierają się reprezentacji. Możliwe jest wyłącznie nieporadne świadczenie, podobne zresztą do tego, którego dokonuje Lipski w przywołanym przed chwilą fragmencie. Właśnie ocalanie od zapomnienia uzasadnia dalsze funkcjonowanie podmiotu:

Sarni braciszek. Chcę tu opisać rzecz tak delikatną, że zdaje mi się, wspomnieniem zniszczę ją. Wyłania się ona czy ono z dalekiej pamięci, zamazane, zniszczone, w strzępach. Nie potrafię nazwać ani imion, ani zdarzeń, bo się wstydzę, że ich nie pamiętam, [...] i żałuję, $\mathrm{i}$ jestem dumny. W każdym razie te zdarzenia wyłaniają się z oparu, z mgły i zapadają się w nią, jeśli usiłuję cokolwiek sobie przypomnieć. Jestem zmuszony do pisania o czymś, o czym wiem, że nie wiem.

$[\ldots]$

Dlaczego, dlaczego muszę o tym pisać, jedyny istniejący trochę człowiek nad, dlaczego, na miłość boską. [P 93]

Rozpaczliwe pytanie o przymus opowiadania jest w rzeczywistości pytaniem o przyczyny ocalenia ,człowieka nad” i o zasadność egzystencji ,w świecie »po«”. Walka z chimeryczną pamięcią okazuje się walką z samym sobą - zmaganiem z ambiwalentnym żalem, ale i z własną dumą czy ambicją. Największą wagę ma chyba jednak poczucie wstydu, które zresztą wymusza określone postawy. W egotykach pisarz deklaruje radykalne odwrócenie się od doczesności: „Moja samotność musi być na wskroś świecka" (P 79). Następnie w trybie imperatywu postanawia: „Istnieć jak upiór, na zboczu życia, istniejąc trochę, niezupełnie, w mroku” (P 55).

17 Ciekawy wydaje się (wielowymiarowy) wątek wstydu u Lipskiego - C u b e r (op. cit., s. 64) stwierdza wprost, że bohater jest ,skruszony przez zachodnią kulturę i judaistyczny patriarchalizm; ciąży na nim ogromna pokusa, by dać się osądzić”. O innych aspektach tego zagadnienia zob. K. Te 1 e jk o, Motyw wstydu w prozie Leo Lipskiego. „Midrasz” 2009, nr 9. 
Potrzeba pokuty przejawia się także w akcie uniżenia, dokonującego się w momencie wywieszenia nad głową Piotrusia szyldu: „PIOTRUŚ WRAZ Z ODZIEŻĄ - DO SPRZEDANIA", i wystawienia na telawiwskim targu (co z kolei narrator tłumaczy przymusem „okoliczności i długów moralnych" $\langle$ Ś 75$\rangle)^{18}$. Demonstrowanie chęci zadośćuczynienia wiąże się z poszukiwaniem sensu egzystencji i z pragnieniem oddania należnej czci nieobecnym. Motywację bohatera trafnie rozpoznaje izraelski lekarz:

- Otóż właśnie. Każdy z nas chodzi do ubikacji. I pan sobie tam urządził prywatną Golgotę. I panu niewygodnie jest w pluszowym fotelu.

Głos doktora potężniał. Istotnie poczułem się niewygodnie.

$[\ldots]$

- [...] I gdzie pan nie odczuwa bólu? O, wielki Piotrusiu. Czyżby pan cierpiał za całe nieudane pokolenie? [...]

$[\ldots]$

- [...] Infantylizm. Ekshibicjonizm. Masochizm. Tajemnica życia i śmierci. [Ś 120-121]

„Wychodkowa” egzystencja staje się zatem synonimem ofiarności, ale i sprzeciwu wobec bezrefleksyjnego trwania, bycia „pomimo” przeszłości i dystansowania się wobec bolesnych doświadczeń. Piotruś - choć faktycznie po trosze infantylny, masochistyczny, na swój sposób lubujący się w ekshibicjonizmie i kontemplujący cierpienie - nie wydaje się jednak bohaterem traumatycznym ${ }^{19}$. Neurotyczność i kompulsywność jego poczynań sterowane są bowiem chęcią przepracowania własnych przeżyć i jednocześnie poszukiwaniem adekwatnych form ekspresji, a co za tym idzie - świadczeniem o minionym. Konieczność pokuty zbiega się z imperatywem pisania. Kryzysowi reprezentacji odpowiada jednak kryzys języka.

\section{Faktury tekstu. Kalekie słowa}

Podobnie jak trudna i niedoskonała jest mowa dotkniętego częściową afazją Lipskiego (i jego bohaterów, m.in. jąkającego się Piotrusia), tak problematyczna okazuje się ekspresja artystyczna. Prawidłowość tę można zaobserwować na poziomie nie tylko tematyki, lecz również formy, o czym zresztą przekonywał Michał Sambor, mówiąc o charakterystycznym dla analizowanego autora ,ścisłym przyleganiu stylu do wizji” ${ }^{20}$. Nie przypadkiem dzieło Lipskiego cechuje fragmentaryczność, eliptyczność, niekiedy zanikanie chronologii i ciągów przyczynowo-skutkowych, segmentacja wywodu oraz stopniowy rozpad, objawiający się zrywaniem fikcyjnych więzi (szczególnie widoczny w wątkach dotyczących Zagłady), odchodzeniem od zasad interpunkcji, ortografii i stylistyki, wreszcie - rozmywaniem

${ }^{18}$ Co znamienne, gest radykalnego poświęcenia się widoczny jest już w motcie inicjującym narrację Piotrusia, pochodzącym z Nocy i dni M. D ą b r o w s k i e j (z tomu Miłość): „Kto odda się cały jednej, wielkiej czy małej, sprawie, w dodatku beznadziejnej - ten musi umrzeć w końcu za nią albo też przez nią" (Ś 75).

19 Polemizuję tu z ciekawą i kuszącą, lecz - jak mniemam - zbyt mocną (zważywszy na fakt podejmowania prób zmierzenia się z problemem) tezą G o s k (op. cit., rozdz. Przypadek Piotruś. Bohater traumatyczny), nazywającej tak Piotrusia.

${ }^{20}$ M. S a m b o r, Uwagi o prozie beletrystycznej. W zb.: Literatura polska na obczyźnie 1940-1960. Red. T. Terlecki. T. 1. Londyn 1964, s. 179-180. 
się reguł kompozycyjnych ${ }^{21}$. Często odnajduje się w tej prozie urywane równoważniki zdań, zdania pojedyncze, wyliczenia, ciągi czasowników zastępujące całe zdania $^{22}$. Zabiegi owe wytwarzają swoisty „efekt Lipskiego" ${ }^{23}$, tzn. nieład, chaotyczność wypowiedzi, pozorny brak dbałości o formę sugerują „kruszenie”, wyczerpywanie się czy ,gnicie” języka.

Sam autor raz po raz zdradza: „Język, którym myślę, rozpada się i kruszy” (Ś 88), z kolei „Słowa są jak ranne ptaki przelatujące morze” (S 87). Wewnętrzny przymus pisania okazuje się jednak silniejszy; Lipski tłumaczy: ,gdy widzę papier, dostaję mdłości i słyszę, że jest we mnie cicho jak w trupiarni...”; „Obrazy leżą we mnie zastygłe, wyschnięte jak rośliny w zielniku [...]” (Ś 18). Świadomość zostaje zatem sprowadzona do funkcji archiwizowania minionych widoków, głosów i doznań. W krótkim utworze prozatorskim Święty Paweł mówi Lipski o powojennym zmaganiu się ludzi pióra z afektywnymi przeżyciami, o tym, że zmuszeni oni są: „Przechodzić wytartą, oślinioną drogę odysei. Tysiącami piszą, sepleniąc, ślimacząc się, wyciskają uroczyście swoje męki, jak wągry, swoje nienawiści i zły los" (Ś 18). Tworzenie jawi się w takich razach jako jedna z funkcji fizjologicznych ${ }^{24}$.

W przypadku samego Lipskiego nie tylko choroba świadomości, ale też defekty cielesności niejako infekują, piętnują wszelkie próby werbalizacji. Wobec tego impasu dochodzi do uspójnienia projektu egzystencjalno-artystycznego. Literacka mowa Lipskiego okazuje się czymś więcej niż ,somatopisaniem” czy dyskursywizowaniem traumy i afektu. Owa ekspresja jest wszystkim tym naraz, lecz przede wszystkim - stanowi unikalny casus pisania kalectwem ${ }^{25}$.

W wymienionym akcie zawiera się także odpowiedź Lipskiego na Adornowskie pytanie o zasadność tworzenia po Zagładzie ${ }^{26}$ :

Papier jest bezczelnie biały. Chodzę koło niego jak pies dookoła suki. Krążę uparcie. [...] $[\ldots]$

[...] Czekam, aż obrazy podniosą się przede mną, jak przed zaklinaczem węże, obrazy owszonych i żywych, wciskających usta w wargi trupów, obejmujących ich udami, aż zmieszają się w wielkim składzie potu, strachu i otępienia i odsłonią to, co było przedtem - iżby okazało się, że ja, który byłem przeznaczony śmierci, stałem się dla żywota, że zostałem zabity, by stworzyć życie ze zdań i słów, które wyrośnie na nawozie ze mnie i z tych, co zginęli.

I wydaje się to nagle najbardziej proste i wielokrotnie perwersyjne, droga prymitywna,

${ }^{21}$ Zob. Krupiński, op. cit., s. 63.

${ }_{22}$ Zob. Go s k, op. cit., s. 20, 37, 61 .

${ }^{23} \mathrm{C}$ u be r (op. cit., s. 50) porównuje Lipskiego do A. Ważyka, ,poety myślowych rygorów i składniowych zerwań”, wykorzystującego „standardową łączliwość składniową jako ślad zmurszałego i nie istniejącego już wtedy świata".

${ }^{24} \mathrm{C}$ u b e r (ibidem, s. 56-66) analizuje z tej perspektywy proces zarówno czytania, jak i pisania Lipskiego: to pierwsze przedstawiane jest wówczas jako kompulsywne wchłanianie, jedzenie, pożeranie; to drugie również ma charakter nerwicowy, „,biologiczny”, ale „nie systematyczny” obrazowany jako blokada, kolka, obstrukcja, rozwolnienie i wydalanie.

${ }^{25}$ K r u pińs ki (op. cit., s. 56) nazywa projekt Lipskiego „cierpieniopisaniem”. Chociaż uważam to określenie za trafne, trudno mi zgodzić się z zawężeniem jego potencjału znaczeniowego, z odnoszeniem go wyłącznie do cierpienia fizycznego i z przekonaniem, iż „tematyka oraz forma konsekwentnie grawituje ku milczeniu" - wydaje się wszak, że głównym zamysłem i dążeniem Lipskiego jest świadome przekraczanie wymiarów traumy, pustki, niewyrażalności, milczenia.

${ }_{26}$ Th. W. A d o r n o, Dialektyka negatywna. Przeł., wstęp K. K r z e m i e n i o w a. Współpraca S. Krze mi én - O j a k. Warszawa 1986, s. 509. 
zwycięska i przewrotna. Czy będę pół bogiem, pół czarnoksiężnikiem, aby mieszać, lepić i rozpładzać ludzi? [Ś 18-19]

Osobliwe „zapładnianie” papieru materią wspomnień jest wyczerpującym procesem wydobywania wrażeń $\mathrm{z}$ dna świadomości i jednocześnie etycznym, ocalającym gestem mogącym uzasadniać dalsze funkcjonowanie. Ukazuje bowiem sens trwania temu, kto postrzega swoje ocalenie jako przypadkowe, czyje ciało przetrwało, lecz umysł ,został zabity” wraz z innymi ofiarami.

Ów proces ,,wskrzeszania” jednostki, mającej „stworzyć życie ze zdań i słów, które wyrośnie na nawozie” z niej ,i z tych, co zginęli”, przywodzi na myśl ogólniejszą prawidłowość. Po raz kolejny ujawnia się wszak upodobanie Lipskiego do metafor odwołujących się do biologicznej cykliczności, do obiegu materii, recyklingu. Mechanizm ów trafnie opisuje Barbara Zielińska, eksponując szczególnie „biocykliczne” aspekty omawianej prozy:

Język Piotrusia odznacza się szczególną predylekcją do zapisywania najróżniejszych odmian ruchu, krążenia, oplatania, pulsowania biologii. Mimo deklarowanej atrofii język ocala płynne, obłe kształty. Krążenie krwi, krążenie wspomnień, arterie zapachów, arterie żydowskiej neurozy. Spuszczanie wody w klozecie marki Niagara [...]. [...]

[...] W ten sposób przemawia cykliczność, wiecznie odradzająca się biologia, dla której żadna śmierć nie jest kresem, więc tutaj nawet zmarli „odpływają nieustannie na grzbietach fal", zostawiając miejsce żywym ${ }^{27}$.

Faktycznie, Lipskiego ewidentnie fascynuje nieprzerwany obieg materii w przyrodzie, płynność następowania w łańcuchach pokarmowych, determinizm życia i śmierci, a także recyklingowość ludzkiej działalności. Stąd też zapewne dobór specyficznego budulca tej sztuki, wpisującej się zresztą w koncepcję Theodora W. Adorna, twierdzącego: „Wszelka kultura po Oświęcimiu, włącznie z jej najwnikliwszą krytyką, jest śmietniskiem" ${ }^{28}$. Sztuka jako taka musi być odtąd wywlekaniem brudów, grzebaniem w odpadkach, obserwowaniem kumulujących się nieczystości i stopniowej dezintegracji. Właśnie najbardziej prymitywna materia może być jedynym półfabrykatem pozagładowego dzieła, głównie dlatego, iż stanowi kwintesencję świata bez transcendencji - wywodzi się bezpośrednio z ludzkiego ciała i jako taka lokuje się najbliżej indywidualnego doświadczenia. Pośledni status śmieci i kruchej materii symbolicznie odpowiada zatem ,kryzysowi” języka i kultury, nadwątlonych przez wydarzenia epoki.

Koncepcja Lipskiego nie jest jednakże skrajnie pesymistyczna. W obranej stylistyce i w ponownym używaniu tego, co zmurszałe, kalekie, zużyte czy rozproszone, upatruje pisarz szanse odnowy. Prawidłowość ta cechuje, jak sądzę, całą twórczość autora Piotrusia i polega na „recyklingowej” obróbce faktur materii, historii, pamięci i słów. Mechanizm ów uwidacznia się wielorako, m.in. w sposobie budowania narracji, w jawnej intertekstualności, ale też w ciągłym „krążeniu” czy rotacyjności pewnych (wymienionych już) motywów, obrazów, metafor, problemów itd. Ciekawe tło przywołuje Marta Cuber, doszukując się analogii między wizją Lipskiego a regułami braminizmu:

\footnotetext{
${ }^{27} \mathrm{Z}$ i e li ńs k a, op. cit., s. 38-39.

${ }^{28}$ Adorno,op. cit., s. 515.
} 
Resztka żywności w braminizmie budzi ten sam wstręt, co odchody w kulturze zachodniej. Zanieczyszcza z racji pozostałości i niekompletności, ale kalając, przyczynia się jednocześnie do odnowy (zjadłszy resztkę, kapłan staje się zdolny do aktu ofiarnego). Ambiwalencja resztki, tak jak odchodów, polega więc na spotkaniu świętości i świeckości, czystości i wstrętu, cofania się, ale i odnowy w jednym, niebywale trudnym do pojęcia przez kulturę Zachodu, rytuale. Podobnie jej moc działa w Niespokojnych: zjadłszy wielokrotnie strawioną i zwymiotowaną organiczną pozostałość, podmiot układa z niej narrację, ostentacyjnie nieukończoną, wtórną, zapośredniczoną w literaturze (jawnie intertekstualną) ${ }^{29}$.

Pobrzmiewający w uprzednio przytoczonym fragmencie profetyczny ton Lipskiego - „zaklinacza”, „pół boga, pół czarnoksiężnika” - odpowiadałby w tym układzie komuś świadomemu mocy rytualnego łączenia nietożsamych potencjałów, kogoś pragnącego sprawczości podejmowanych działań. Wydaje się, że owa sprawczość osiągnięta zostaje w wymiarze oddziaływania tekstowego. Okazuje się bowiem, że dla Lipskiego pisanie jest nie tylko (po pierwsze) próbą utrwalenia przeżycia afektywnego (,wyciskaniem swoich mąk”) czy (po drugie) doświadczeniem samym w sobie (,przechodzeniem wytartej drogi odysei”), lecz także (po trzecie) doświadczaniem odbiorcy (poddawaniem go próbie, ale i wywoływaniem doznań), do którego Lipski zwraca się wprost, inicjując narrację o życiu obozowym:

To wszystko już znacie i z tego będziecie zaraz rzygać. Ale zaczekajcie.

[...]. Może wy też znajdziecie coś takiego, na co będziecie mu s i e li patrzeć. [Ś 39]

Specyficzna poetyka, siła wyrazu, ostrość kontrastów mają przede wszystkim wpływać na czytelnika - jednakże nie poprzez wikłanie w sieć empatycznych utożsamień. Metoda Lipskiego opiera się raczej na konsekwentnym zadziwianiu, prowokowaniu, wytrącaniu z lekturowych przyzwyczajeń i na stopniowym ,infekowaniu” własnym świadectwem: „Ludzie, sami żywi, promieniują swoimi zmarłymi. Ludzie, nosiciele śmierci [...]. Ja też jestem takim człowiekiem. Jasne, że moja opowieść jest śmiertelna" (S 62). Lipski jawi się jako nosiciel śmierci i pamięci, co znaczy, że (w odróżnieniu od biernego nośnika) aktywnie poszukuje odnowy w niestrudzonym przypominaniu. Owo „nosicielstwo" ma charakter sprawczy, „wielokanałowy”, świadomościowy, cielesny, ale i performatywny, „zarażający”. Opowieść prozaika okazuje się bowiem „śmiertelna” na co najmniej kilku poziomach: dotyczy śmierci; sama musi „umrzeć”, przeminąć, ale też jest „śmiercionośna”, trudna do zniesienia, nieprzejednana, wyniszczająca samego autora (,Kto odda się cały jednej, wielkiej czy małej, sprawie, w dodatku beznadziejnej - ten musi umrzeć w końcu za nią albo też przez nią”) i „promieniująca” na czytelnika („Gdy jemu się coś stało, to nie mamy prawa istnieć, ani ja, ani Ty”). Dramatyczny proces twórczy to więc ocalanie, pokuta i świadczenie zarazem. Lipski w kreacyjnym akcie „mieszania i lepienia” faktur historii, pamięci i ciała ustanawia dopominające się istnienia tekstowe byty. Owo pisanie - podobnie jak klozetowe życie Piotrusia - okazuje się dobrowolnym oddaniem, uniżeniem i upokorzeniem, prywatną golgotą, na którą tr z e b a patrzeć.

${ }^{29} \mathrm{C}$ u b e r, op. cit., s. 61. 
Abstract

AGNIESZKA DAUKSZA

(Jagiellonian University of Cracow)

\section{BEARER OF MEMORY. ON REMEMBERING, HANDICAP AND WRITING IN LEO LIPSKI'S LITERARY CREATIVITY}

The article is an attempt to such reading of Leo Lipski which points at the legitimacy of specific, still insufficiently understood and described, convention adopted by the author in question. Lipski's creativity is seen not only as a testimony of searching for his own diction but also as a struggle to overcome postwar deadlock, stepping outside the rhetoric of the inexpressible, incapacity of expression, emptiness, and ultimately an attempt at overcoming the crisis of language and representation. Important in this view is a demonstration of the interdependence of three orders, namely the framework of memory, the matter, and the text. Particularly painful memory about Shoah proves to be foundational to the analysed prose on many levels, both thematic and conceptual, linguistic and stylistic. 